\title{
Nicotinic Acid, Pantothenic Acid and Biotin in Fruits, Vegetables and Nuts
}

\author{
By DILYS P. JAMES \\ University of Bristol Research Station, Long Ashton
}

(Received 8 November 1950)

Little information is available about the vitamins of the B group (with the possible exceptions of aneurin and riboflavin) in fruits and vegetables, particularly those most widely cultivated in the British Isles. The riboflavin contents of home-grown fruits have been surveyed by the author (James, I944). This paper records estimations, made in the 1947 and 1948 seasons, of nicotinic acid, pantothenic acid and biotin in fruits, vegetables and nuts commonly found in English gardens and hedgerows.

\section{EXPERIMENTAL}

\section{Materials and methods}

During the 1947 season assays were made on fourteen kinds of fruit, comprising thirty varieties. With the exception of cherries, all fruits were grown in the Research Station plantations under normally good conditions of cultivation. Soft fruits, stone fruits and gooseberries were picked at the best stage of maturity for cooking or dessert, depending on variety, and extraction for assay was begun within the hour. Pears were picked when slightly immature and ripened at room temperature. Apples of keeping varieties were sampled $\mathrm{I}$ week after picking in October and again after storing at $36^{\circ} \mathrm{F}$ for $10-12$ weeks, when they were fully ripe. The cherries came from Kent and were assayed not more than $24 \mathrm{~h}$ after picking.

In 1948 some twenty-three different vegetables and seven kinds of nuts were assayed at the stage of maturity considered to be best for palatability. Most of the vegetables were grown at the Research Station and used immediately after gathering. A few were obtained locally and the asparagus was grown in the Evesham district, the assays being made $24 \mathrm{~h}$ after harvesting.

The nuts were obtained from hedges, gardens and plantations in Somerset and Kent, and were allowed to ripen in their shells at room temperature before assay.

\section{Measurements}

Nicotinic acid, pantothenic acid and biotin were assayed by microbiological methods based on those published by Barton-Wright (1944, 1945, not dated); the test organism was a subculture of the strain of Lactobacillus arabinosus used by him. The development of microbiological assay methods has made it possible to undertake certain vitamin estimations in laboratories where such work was hitherto not attempted because of the lack of suitable chemical methods or of the time, space and labour required for biological assays. The varying degree of success with which microbiological methods 
have met appears to have been due to variations in technique, equipment, reagents and treatment of the test organism; these have not always been reported or even appreciated by the worker.

There also remains the fact that we know the microbiological methods to work, but that the precise nature of cell activity involved in an assay is still uncertain. A detailed account of the methods used is therefore given here, so that the accuracy of the results obtained can be assessed and compared with those of other workers at the present time and in the light of future knowledge.

\section{Sampling}

Fruits. A representative sample (at least six apples or pears), sufficient to give about $500 \mathrm{~g}$ prepared edible portion, was taken from each batch of fruit.

Soft fruits were hulled and washed when necessary; stone fruits were wiped with a dry cloth, stems and stones being then removed; hard fruits were peeled and cored; gooseberries were topped and tailed; hairs and seeds were removed from rose-hips, and tomatoes were merely wiped.

Vegetables. As with the fruits, each lot of vegetables was sampled so as to give about $500 \mathrm{~g}$ edible portion for extraction. Peas and dwarf beans were shelled, the seeds only being used, and runner beans were wiped and both pods and seeds used. Leafy vegetables were washed and wiped and inedible parts of the stalk removed. For large leafy vegetables, such as savoy cabbage and cabbage lettuce, longitudinal quarters or halves from several plants were bulked to form the sample. Cauliflowers were similarly sampled and divided into flower, leaf (including edible stalk and midrib) and inedible stalk. Roots and tubers were washed and scraped or peeled, according to custom; when individual vegetables were large, longitudinal quarters from at least six specimens were again taken. Celery heads were halved longitudinally and several halves were divided into stem and leaf samples, which were washed and wiped before using. Samples of asparagus included tips and edible stems, whereas only the flesh of marrow was used, the method of longitudinal sectioning being again employed. About 2 in. of edible green leaf were included in samples of leeks; the outer brown layers of onions were removed.

Each bulk sample of fruit or vegetable was either minced in a stainless domestictype machine or macerated in a Waring Blendor. At least two ro- $5 \circ \mathrm{g}$ portions of the thoroughly mixed sample were weighed for assay.

Nuts. The kernels were peeled and about $5 \mathrm{~g}$ finely chopped material were ground in a mortar with fine, purified sand.

\section{Extraction}

Observations by the author (James, 1947) and others, confirmed by Kodicek \& Pepper (1948), have shown $L b$. arabinosus to be relatively insensitive to stimulation by fats and fatty acids when compared with $L b$. helveticus, which is used in the assay of riboflavin. With materials of high fat content such as nuts it was, however, found necessary to extract samples for Io $\mathrm{h}$ with ether in a Soxhlet apparatus before 
attempting aqueous extraction of the vitamin. From the defatted bulk sample of each variety samples were taken for vitamin extraction.

The following simple procedure was adopted; by its means assay of the three vitamins could be made on a single extract. The same extract could also be used for the assay of riboflavin with $L b$. helveticus.

Two weighed portions of the minced bulk sample were finely blended with $40 \mathrm{ml}$. acetate buffer $\left(\mathrm{pH}_{4} \cdot 5\right)$, transferred into $600 \mathrm{ml}$. conical flasks, covered with inverted beakers and autoclaved for $15 \mathrm{~min}$ at $15 \mathrm{lb}$. pressure. After cooking, $20 \mathrm{mg}$ of pure papain (Ferris \& $\mathrm{Co}$ ) and $20 \mathrm{mg}$ takadiastase (Parke, Davis \& Co.) were added to each fruit extract and ten times that quantity to nut and vegetable extracts. When several samples were extracted the total amount of enzymes required was blended with a few drops of glycerol and made up to a convenient volume with distilled water. Appropriate volumes of this enzyme preparation were then pipetted into each extract. Vegetables that had proved difficult to macerate before autoclaving, and those that had formed a thick sludge or starchy gel during autoclaving, were further ground before being blended with the enzymes in a mortar. Each extract was covered with a layer of toluene and incubated at $37^{\circ}$ overnight (16-18 h). At first blank extracts, containing only buffer and enzyme preparation, were prepared and assayed in the same way as test extracts. As they consistently gave negligible values for nicotinic acid, biotin and pantothenic acid, this procedure was discontinued as a routine measure, but repeated occasionally. When extracts were to be assayed also for riboflavin, enzyme blanks were required.

After incubation the extracts were steamed for $30 \mathrm{~min}$ to stop enzyme activity. The deposit was removed by squeezing the hot incubate through double muslin; it was then washed well with distilled water, the whole aqueous extract being collected in a graduated flask. After cooling the $\mathrm{pH}$ was adjusted to 6.8 (bromothymol blue) with sodium hydroxide and acetic acid, and the extract was made up to the required volume. At this stage all extracts were shaken with chloroform, the chloroform layer being then centrifuged off and the clear aqueous layer retained for assay. Shaking with chloroform may or may not have been necessary for removal of fat and fatty acids, but it provided a safe and simple means of clarifying the extracts. Extracts so prepared were clear and generally colourless. In others the very light colour remaining did not interfere with subsequent titration of lactic acid. Usually extracts were assayed immediately after preparation, but it was found that they could be kept at $4^{\circ}$ under toluene in close-stoppered bottles for 3 weeks without loss of vitamin.

\section{Microbiological assay}

Each extract was assayed at three or more different levels and triplicate readings were made at each level. For each vitamin, standard curves were obtained from a series of twenty-one flasks containing the vitamin at seven different concentrations.

It was found convenient to use $50 \mathrm{ml}$. conical flasks for all assays. These had the advantage over test-tubes that the final titration could be made directly in them; they were also easier to fill. Into each assay and standard flask exactly $5 \mathrm{ml}$. of the appropriate double-strength basal medium were run from a burette, a suitable volume of the 
extract under test, or of the pure vitamin in solution, was added by pipette, and the volume in each flask was brought up to $9.5 \mathrm{ml}$. with distilled water.

No difference was found in assays when the normal laboratory supply of water from tin-lined copper stills was used instead of the glass- or porcelain-distilled water recommended by other workers. Analyses of this water showed an average per litre of $0.004 \mathrm{mg}$ iron, $0.004 \mathrm{mg}$ manganese, $0.014 \mathrm{mg}$ copper, $0.0075 \mathrm{mg}$ zinc, $0.003 \mathrm{mg}$ boron and $0.00035 \mathrm{mg}$ molybdenum. The quantity of copper was evidently too low to interfere with the growth of $L b$. arabinosus, and the ordinary laboratory supply of distilled water was used in the preparation of all extracts and mediums. The same result had previously been found in $L b$. helveticus assays of riboflavin.

The flasks were plugged with cotton-wool of different colours to distinguish assays of different vitamins, with various combinations of colours to indicate various levels of concentration. All standard and assay flasks for the same vitamin were autoclaved together for $15 \mathrm{~min}$ at $\mathrm{I} 5 \mathrm{lb}$. pressure. With this treatment the biotin medium remained almost colourless and the nicotinic-acid and pantothenic-acid mediums pale yellow. Longer sterilizing even at a lower temperature caused the mediums to darken, making subsequent titration difficult.

The basal medium used in assay of each vitamin was that recommended by BartonWright (not dated), the $\mathrm{pH}$ being always adjusted to 6.8. Details are given in Table $\mathrm{I}$. Both commercially prepared vitamin-free spray-dried casein hydrolysate and a casein hydrolysate prepared here have been used with equal success. When in 1947 this work was due to begin, no $p$-aminobenzoic acid was available and assay trials were made without it. The organism responded excellently and when later $p$-aminobenzoic acid was available its addition to the mediums produced no change in biotin and nicotinic-acid assays, but increased the production of acid in the assay of pantothenic acid, as shown by the following titrations:

\begin{tabular}{|c|c|c|}
\hline \multirow[b]{2}{*}{$\begin{array}{c}\text { Pantothenic acid } \\
(\mu \mathrm{g})\end{array}$} & \multicolumn{2}{|c|}{$\begin{array}{c}\text { Growth response expressed in terms of } \\
\text { approx. } 0.1 \mathrm{~N}-\mathrm{NaOH}\end{array}$} \\
\hline & $\begin{array}{c}\text { Medium without } \\
\text { p-aminobenzoic acid } \\
\text { (ml.) }\end{array}$ & $\begin{array}{c}\text { Medium with } \\
\text { p-aminobenzoic acid } \\
\text { (ml.) }\end{array}$ \\
\hline 0.0 & 0.7 & 0.72 \\
\hline 0.005 & 1.02 & $x \cdot 47$ \\
\hline $\begin{array}{l}0.01 \\
0.02\end{array}$ & $\begin{array}{l}I \cdot 61 \\
2.4\end{array}$ & $\begin{array}{l}2 \cdot 49 \\
4 \cdot 2\end{array}$ \\
\hline 0.04 & $3: 34$ & $6 \cdot 05$ \\
\hline 0.06 & 3.95 & $7 \cdot 24$ \\
\hline 0.08 & $4 \cdot 35$ & $8 \cdot 25$ \\
\hline
\end{tabular}

The strain of $L b$. arabinosus employed would therefore appear to be the $p$-aminobenzoic acid mutant described by American workers and later by Kodicek \& Pepper (1948). The inclusion of $p$-aminobenzoic acid in the mediums was continued in anticipation of the organism's reversion to type, but recent tests have shown that it is still able to dispense with $p$-aminobenzoic acid.

The inoculums were prepared by growing the organism overnight in basal mediums enriched with the missing vitamins. Stock cultures of the organism were carried on 
slopes of yeast-extract agar containing I \% glucose and were usually subcultured at weekly intervals. It was found unnecessary to hold them at $4^{\circ}$ after incubation; cultures kept at room temperature for 3 weeks showed no change in response during assays. Two tapered centrifuge tubes were charged with $3 \mathrm{ml}$. nicotinic-acid assay basal medium, $3 \mathrm{ml}$. distilled water and $\mathrm{I} \cdot 2 \mu \mathrm{g}$ nicotinic acid. They were plugged and

Table r. Composition of basal mediums used in the microbiological assays. Quantities for fifty flasks (double strength)

\begin{tabular}{|c|c|c|c|c|}
\hline Nutrient & $\begin{array}{l}\text { Strength } \\
\text { of stock } \\
\text { solution } \\
\text { (wt./ml.) }\end{array}$ & $\begin{array}{c}\text { For } \\
\text { nicotinic- } \\
\text { acid stock } \\
\text { solution } \\
\text { (ml.) }\end{array}$ & $\begin{array}{c}\text { For } \\
\text { biotin } \\
\text { stock } \\
\text { solution } \\
\text { (ml.) }\end{array}$ & $\begin{array}{l}\text { For } \\
\text { pantothenic- } \\
\text { acid stock } \\
\text { solution } \\
\text { (ml.) }\end{array}$ \\
\hline \multicolumn{5}{|l|}{ Solutions: } \\
\hline Photolysed peptone (Difco) & $50 \mathrm{mg}$ & 一 & - & $50 \cdot 0$ \\
\hline L-Cystine & $4 \mathrm{mg}$ & $25 \cdot 0$ & $12 \cdot 5$ & $25 \cdot 0$ \\
\hline DL-Tryptophan & $2 \mathrm{mg}$ & $25 \cdot 0$ & $25 \cdot 0$ & - \\
\hline Adenine and guanine & $\mathrm{I} \mathrm{mg}$ & $5 \cdot 0$ & $5 \cdot 0$ & $5 \cdot 0$ \\
\hline Adenine and uracil & $1 \mathrm{mg}$ & $5 \cdot 0$ & $5 \cdot 0$ & $5 \cdot 0$ \\
\hline Xanthine & I $\mathrm{mg}$ & $5 \cdot 0$ & $5 \cdot 0$ & $5 \cdot 0$ \\
\hline Calcium D-pantothenate & $1000 \mu \mathrm{g}$ & 0.05 & $0 \cdot I$ & - \\
\hline Nicotinic acid & $1000 \mu \mathrm{g}$ & - & $0 . I$ & $0 . I$ \\
\hline Riboflavin & $50 \mu \mathrm{g}$ & $2 \cdot 0$ & $2 \cdot 0$ & $2 \cdot 0$ \\
\hline DL-Biotin & $0.1 \mu \mathrm{g}$ & $2 \cdot 0$ & - & $2 \cdot 0$ \\
\hline Pyridoxine hydrochloride & $100 \mu \mathrm{g}$ & 0.5 & $1 \cdot 0$ & I.O \\
\hline Aneurin & $100 \mu \mathrm{g}$ & 0.5 & 0.5 & 0.5 \\
\hline $\begin{array}{l}p \text {-Aminobenzoic acid } \\
\text { Inorganic salt solution } \mathrm{A} \text { : }\end{array}$ & $100 \mu \mathrm{g}$ & $1 \cdot 0$ & $1 \cdot 0$ & $\mathbf{I} \cdot \mathbf{O}$ \\
\hline $\begin{array}{l}\mathrm{K}_{2} \mathrm{HPO}_{4} \text { (anhydrous) } \\
\mathrm{KH}_{2} \mathrm{HPO}_{4} \text { (anhydrous) }\end{array}$ & $\left.\begin{array}{l}100 \mathrm{mg} \\
100 \mathrm{mg}\end{array}\right\}$ & $2 \cdot 5$ & $2 \cdot 5$ & $2 \cdot 5$ \\
\hline $\begin{array}{l}\text { Inorganic salt solution } \mathrm{B} \text { : } \\
\mathrm{MgSO}_{4} \cdot 7 \mathrm{H}_{2} \mathrm{O}\end{array}$ & & & & \\
\hline $\begin{array}{l}\mathrm{MgSO}_{4} \cdot 7 \mathrm{H}_{2} \mathrm{O} \\
\mathrm{MnSO}_{4} \cdot 4 \mathrm{H}_{2} \mathrm{O} \\
\mathrm{FeCl}_{2} \text { (anhydrous) }\end{array}$ & $\left.\begin{array}{r}40 \mathrm{mg} \\
2 \mathrm{mg} \\
0.4 \mathrm{mg}\end{array}\right\}$ & $2 \cdot 5$ & $2 \cdot 5$ & $2 \cdot 5$ \\
\hline \multicolumn{5}{|l|}{ Solids: } \\
\hline $\begin{array}{l}\text { Casein hydrolysate } \\
\text { Glucose (anhydrous) }\end{array}$ & 二 & $\begin{array}{r}3.0 \mathrm{~g} \\
10.0 \mathrm{~g}\end{array}$ & $\begin{array}{l}1.5 \mathrm{~g} \\
5.0 \mathrm{~g}\end{array}$ & $\begin{array}{r}1.0 \mathrm{~g} \\
10.0 \mathrm{~g}\end{array}$ \\
\hline Xylose (hydrated) & - & $0.5 \mathrm{~g}$ & - & $0.5 \mathrm{~g}$ \\
\hline Sodium acetate (hydrated) & - & $16.5 \mathrm{~g}$ & $5 \circ \mathrm{g}$ & $11.0 \mathrm{~g}$ \\
\hline Sodium chloride & - & $2.5 \mathrm{~g}$ & $2.5 \mathrm{~g}$ & $2.5 \mathrm{~g}$ \\
\hline Ammonium sulphate & - & $\mathrm{I} \cdot 5 \mathrm{~g}$ & $1 \cdot 5 \mathrm{~g}$ & $\mathrm{r} \cdot 5 \mathrm{~g}$ \\
\hline $\begin{array}{l}\text { Water to } \\
\text { Adjust pH to } 6.8 \text { (bromothymol blue) }\end{array}$ & - & $200 \mathrm{ml}$. & $200 \mathrm{ml}$. & $200 \mathrm{ml}$. \\
\hline Water to & - & $250 \mathrm{ml}$ & $250 \mathrm{ml}$. & $250 \mathrm{ml}$. \\
\hline
\end{tabular}

sterilized, and each was inoculated with a loopful of a $48 \mathrm{~h}$ slope culture of $L b$. arabinosus. The two tubes were incubated at $37^{\circ}$ for $16-18 \mathrm{~h}$ and the growths were then centrifuged aseptically, the supernatantmedium being decanted off and the deposits in each taken up in about $6 \mathrm{ml}$. of sterile saline ( $0.9 \% \mathrm{NaCl}$ solution). Aseptic spinning and washing in saline were repeated three times with each tube so as to remove all traces of medium. The final deposit in one tube was suspended in $6 \mathrm{ml}$. sterile saline and $2 \mathrm{ml}$. of this thick suspension were transferred to $50 \mathrm{ml}$. sterile saline to form the inoculum in the pantothenic-acid assay; the remaining $4 \mathrm{ml}$. were taken up in $50 \mathrm{ml}$. saline for assay of nicotinic acid. The deposit in the second tube was suspended in $50 \mathrm{ml}$. saline for biotin assay. This routine method of preparing the inoculums gave 
surprisingly consistent and even suspensions, and with a little experience their opacity could be judged by the eye. A few check counts on a haemocytometer showed that best results were given by suspensions containing I2-15 million organisms $/ \mathrm{ml}$. for nicotinic-acid assay, 15-20 million/ml. for biotin assay, and 4-6 million $/ \mathrm{ml}$. for pantothenic-acid assay.

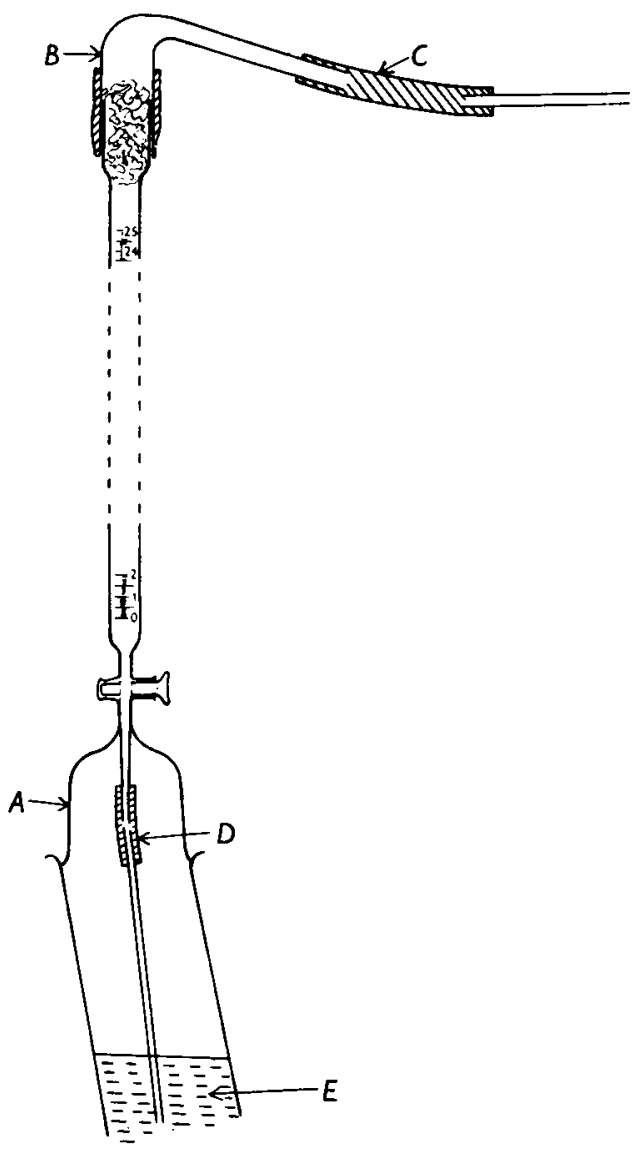

Fig. I. Inoculating burette. For description see this page below.

Inoculation of each assay and standard flask was made with $0.5 \mathrm{ml}$. of the appropriate suspension delivered aseptically from a sterilized shielded burette. The use of sterile pipettes for inoculating 300-400 flasks proved tiring and also increased the chances of contamination by constant opening of the inoculum tube and decreasing steadiness of hand. An inoculating burette was therefore designed; it could be sterilized, filled aseptically and made to deliver the inoculum quickly and accurately. The burette and the method of filling it are illustrated in Fig. $x$.

A glass funnel $A$ was blown on to the stem of an ordinary chemical burette so that the jet was adequately shielded. The burette was cut off at the $25 \mathrm{ml}$. level and the end was plugged with cotton-wool and fitted with a rubber and glass connexion $B$ to which could be attached the mouthpiece $C$ for filling by suction. For autoclaving, the 
funnel $A$ was plugged with cotton-wool and the whole burette fitted into a copper cylinder. Convenient lengths of glass tubing with rubber connexions were autoclaved, separately wrapped or in a plugged boiling tube; when the burette was to be filled, the rubber end of one of these, $D$, was fitted aseptically on to the jet and the glass end flamed and dipped into the suspension, $E$. The mouth of each flask to be inoculated was flamed and held within the shield immediately below the jet, the inoculum being then run in, the mouth of the flask reflamed and the plug replaced. The bacteria remained evenly distributed through the suspension during delivery of $25 \mathrm{ml}$. in $0.5 \mathrm{ml}$. amounts. After a little practice in manipulation, preparing the suspensions, filling the burette and inoculating the flasks could all be done by one junior operator. Two burettes were made and used, one for biotin assays and the other for filling first with the weaker suspensions for assay of pantothenic acid. After being rinsed with sterile water-filling by suction and emptying by gentle blowing through the mouthpiece-it was then filled with the stronger suspension to inoculate flasks for assay of nicotinic acid. Used on an open bench in a room by no means bacteriologically perfect but reasonably free of draughts, these burettes have maintained aseptic delivery for more than $2 \mathrm{~h}$.

Incubation of all assay and standard flasks for $72 \mathrm{~h}$, at $30^{\circ}$ for assays of biotin and pantothenic acid and at $37^{\circ}$ for nicotinic acid, was found to give most consistent results. Observations made here on the effect of temperature differences within the incubator agreed with those of Price \& Graves (1944). Differences between shelves in the incubators used were very slight: from side to side and back to front on the same shelf they were negligible. Each shelf could accommodate seventy-five flasks, i.e. a series of twenty-one flasks for the standard curve and six sets of nine flasks each, for assay of the vitamin in six extracts. Each basket of the autoclave used could also accommodate this number. When more than seventy-five flasks were required for assay of one vitamin, one out of each group of triplicates was incubated on a second shelf and the mean response in each three was taken as the reading. All the flasks used in the assay of the same vitamin were of the same type of glass and had the same base area. They did not require to be shaken during incubation.

Response of the organism in assay of each vitamin was measured by direct titration of the lactic acid produced against sodium-hydroxide solution (approx. O.IN) with bromothymol blue as internal indicator. This method of comparing the response in standard and assay flasks appeared more reliable than comparison by estimations of growth based on turbidity measurement. McIlwain \& Stanley (1948) have shown that the production of lactic acid is proportional to the dose of nicotinic acid, whereas the bacterial growth measured turbidimetrically is not.

All standard and assay flasks involved in the estimation of any one vitamin were removed from the incubator together; all were titrated to the same end-point $(\mathrm{pH}$ about 6.8), which was measured visually, the last flask being titrated as soon as possible after the first. The means of the triplicate readings at each level of pure vitamin or test preparation were plotted to give 'standard' and 'test-preparation' curves. Close agreement between titrations of replicates was usually found. Table 2 shows the results of some typical assays. 


\section{RESULTS}

Typical standard and test-preparation curves obtained in assays of nicotinic acid, pantothenic acid and biotin are shown in Figs. 2-4. Both curves in nicotinic-acid assays were linear over the range of the vitamin assayed. The slope-ratio method of computation (Wood, 1945, I946) could thus be used for calculating the results, which agreed closely with those obtained by direct reading from the standard curve. In

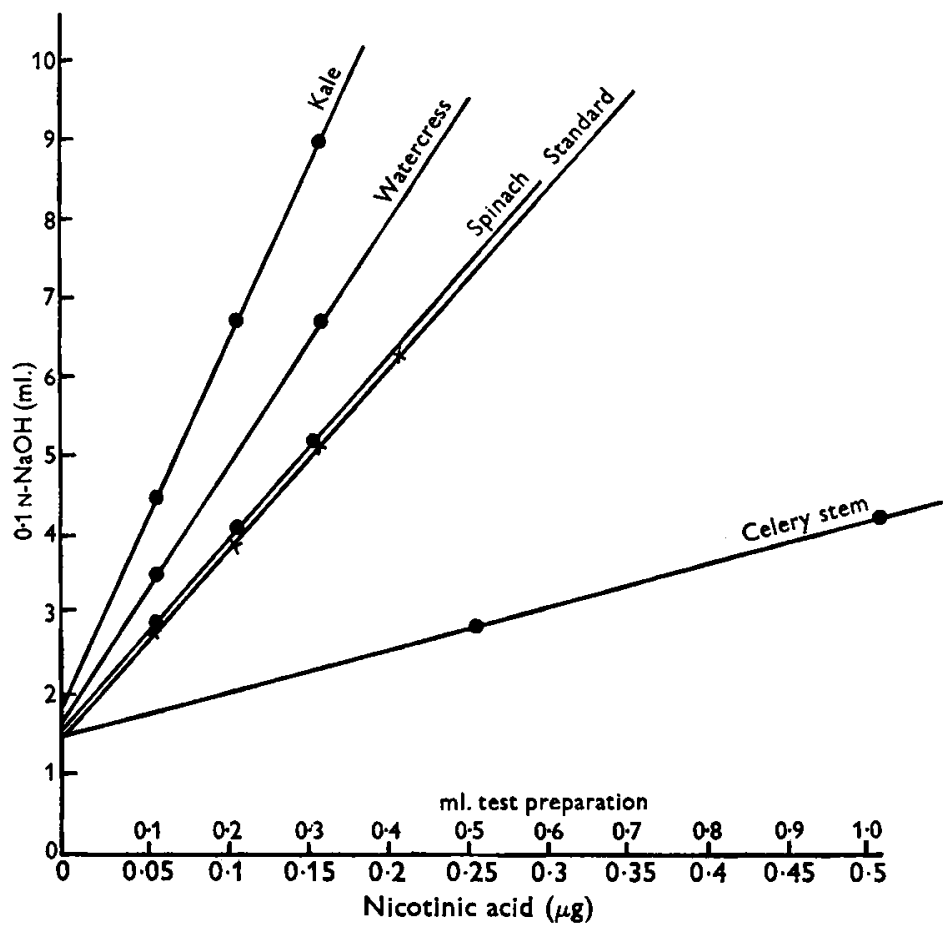

Fig. 2. Nicotinic acid in vegetables. Response of $L b$. arabinosus to a 'standard' solution of nicotinic acid and to test extracts.

assays of biotin and pantothenic acid the single-curve method was used, there being no true linear part of the curve. In both instances smooth curves were readily obtained; with the inclusion of $p$-aminobenzoic acid in the medium, responses to amounts of pantothenic acid up to $0.04 \mu \mathrm{g}$ (occasionally $0.06 \mu \mathrm{g}$ ) were sometimes linear, though not consistently so. With a blank of about $\mathrm{r} \cdot 0 \mathrm{ml}$., omission of $p$ aminobenzoic acid gave titrations of $5-7 \mathrm{ml}$. of approx. $0.1 \mathrm{~N}-\mathrm{NaOH}$ for $0.08 \mu \mathrm{g}$ pantothenic acid, whereas including it gave titrations of $10-12 \mathrm{ml}$. Portions of test preparation were chosen to give readings between $0.0 \mathrm{I}$ and $0.06 \mu \mathrm{g}$ pantothenic acid and 0.00005 and $0.0002 \mu \mathrm{g}$ DL-biotin. When test materials proved unexpectedly potent or weak, assays were repeated to give readings falling within these limits. Concordance was good, results on a single extract at different levels of assay usually agreeing within $\pm 5 \%$ (Table 2).

The nicotinic-acid, pantothenic-acid and biotin contents of a wide range of assayed 
Vol. 6

fresh fruits, vegetables and nuts are given in Tables $3-5$. Varieties giving outstandingly high or low values are mentioned separately and these figures are not included in the mean.

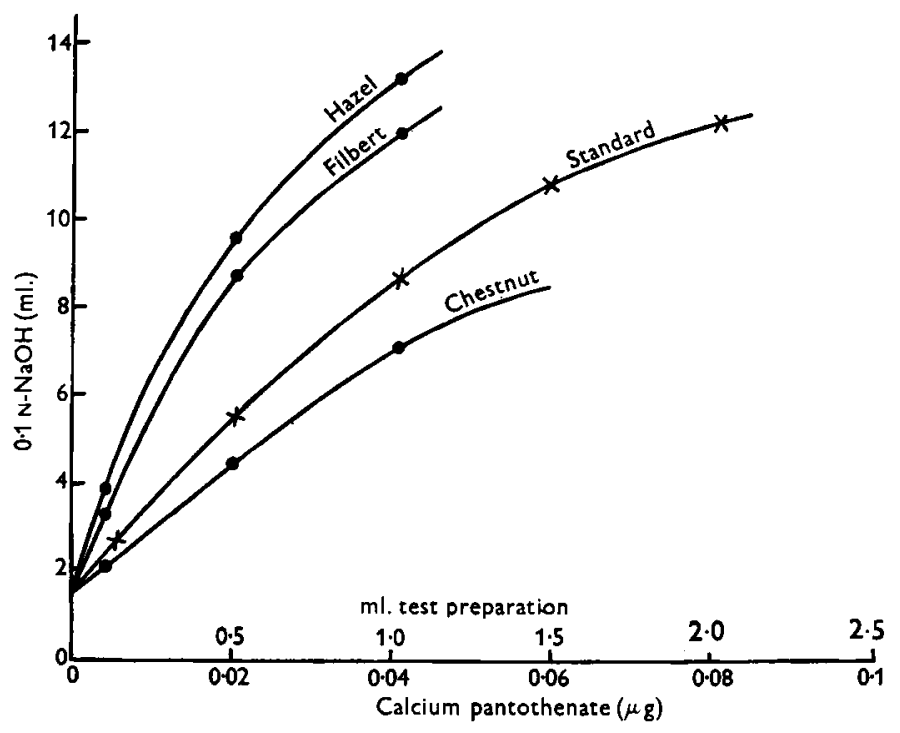

Fig. 3. Pantothenic acid in nuts. Response of $L b$. arabinosus to a 'standard' solution of calcium pantothenate and to test extracts.

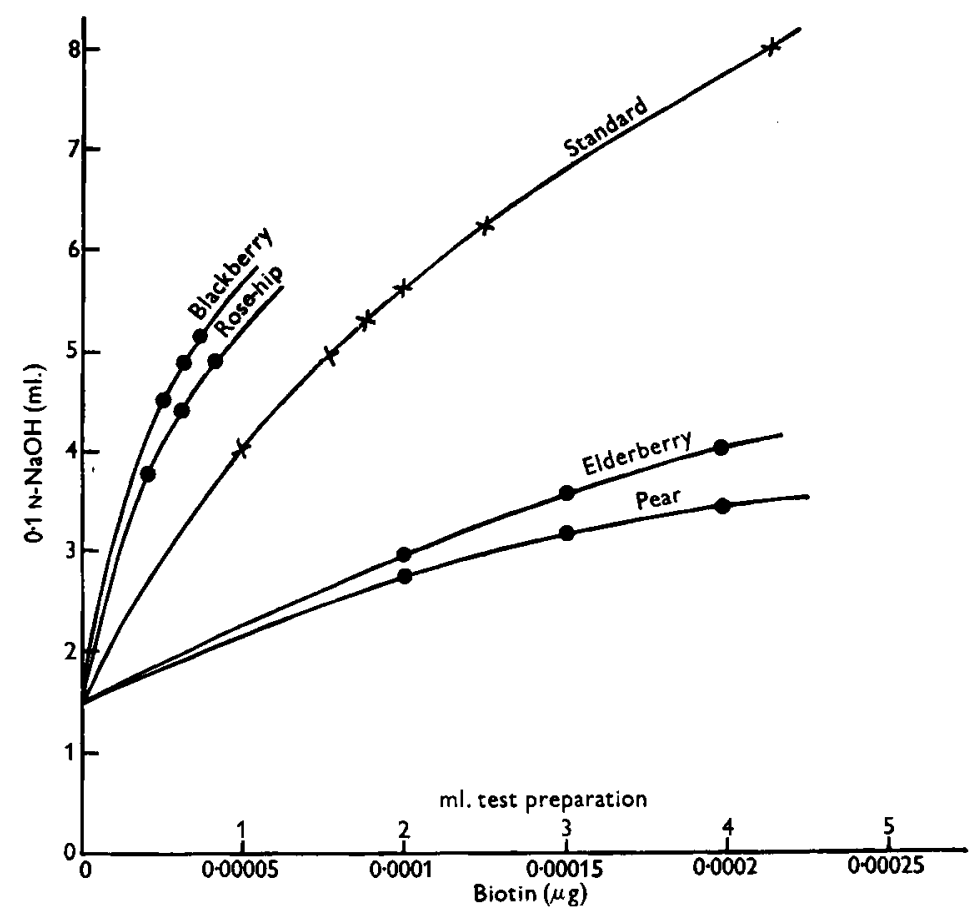

Fig. 4. Biotin in fruits. Response of Lb. arabinosus to a 'standard' solution of biotin and to test extracts. 
Although the method of estimation gave results well within the $\pm 10 \%$ variation commonly allowed in microbiological assays, the number of samples involved varied from twelve for tomatoes to two for asparagus, being intentionally limited so that as wide as possible a range of species could be covered. These values should therefore be regarded only as indicating the general levels of nicotinic acid, pantothenic acid and biotin to be expected in foods of this kind.

Variations due to season or site may occur in the same variety, and this possibility has not been fully investigated. That such variations may be slight is, however, suggested by results in another experiment in which it was necessary to analyse leaves of healthy immature cauliflowers of the same age from sites more than roo miles apart. Values obtained for site I were: nicotinic acid I $15 \circ \mu \mathrm{g}$, pantothenic acid $500 \mu \mathrm{g}$ and biotin $0.16 \mu \mathrm{g} / \mathrm{I} 00 \mathrm{~g}$ leaf respectively, and for site $2,1100,5^{80}$ and $0.37 \mu \mathrm{g} / \mathrm{100 \textrm {g }}$ leaf, respectively. Blackberries and elderberries also gave similar values irrespective of site. Differences between greenhouse and garden tomatoes were insignificant, as were those between parthenocarpic (induced by hormone treatment) and normal fruits. No seasonal variation was observed in a limited number of samples of tomatoes and apples picked from the same sites in 1947 and 1948. No explanation can be offered for the different values shown by plum varieties; all were grown under similar conditions and were picked and assayed at similar stages of maturity. Differences in contents of soluble solids and dry-weight ratios are too small to afford an explanation, and the inclusion in assays of wild yeasts present in surface 'bloom' cannot be considered, as the fruits were thoroughly washed and wiped before extraction. A wide difference was observed between samples of washed and unwashed elderberries, values for nicotinic acid in the unwashed, though apparently clean, fruits being $1800 \mu \mathrm{g} / 100 \mathrm{~g}$, whereas the washed fruit contained $600 \mu \mathrm{g} / \mathrm{r} 00 \mathrm{~g}$. This loss on washing may have been due partly to removal of wild yeasts and also to leaching.

The nicotinic-acid and pantothenic-acid contents of whole turnips were higher than those of peeled turnips, averaging for whole turnips 800 and $260 \mu \mathrm{g}$, respectively. There was, however, no difference between whole potatoes and those peeled or scraped before assay. The fruits examined contained nicotinic acid in amounts ranging from $50 \mu \mathrm{g} / \mathrm{r} 00 \mathrm{~g}$ in Bramley's Seedling apples to $500 \mu \mathrm{g}$ in tomatoes and $600 \mu \mathrm{g}$ in elderberries. Pantothenic acid varied from $40 \mu \mathrm{g} / \mathrm{I00} \mathrm{g}$ in Cox's Orange Pippin to $400 \mu \mathrm{g}$ in black currants and rose-hips (apple again being lowest). Biotin was present in fruits in very much smaller amounts, black and red currants with $2 \cdot 6 \mu \mathrm{g} / \mathrm{roo} \mathrm{g}$ having most; plums had only a trace.

Vegetables, in general, were found to contain higher proportions of these three vitamins than fruits, but again the range was wide. Broad beans and peas were outstandingly high in both nicotinic and pantothenic acids, the former also having the highest biotin content of all the vegetables examined. Parsley (included among the vegetables owing to its frequent use in salads and sauces and its comparatively high content of ascorbic acid and carotene), also was high in nicotinic acid but unexpectedly low in pantothenic. Cauliflower leaves were far richer in nicotinic acid than the flower and stalk, but weight for weight the flower contained more pantothenic acid and biotin. 
Vol. 6

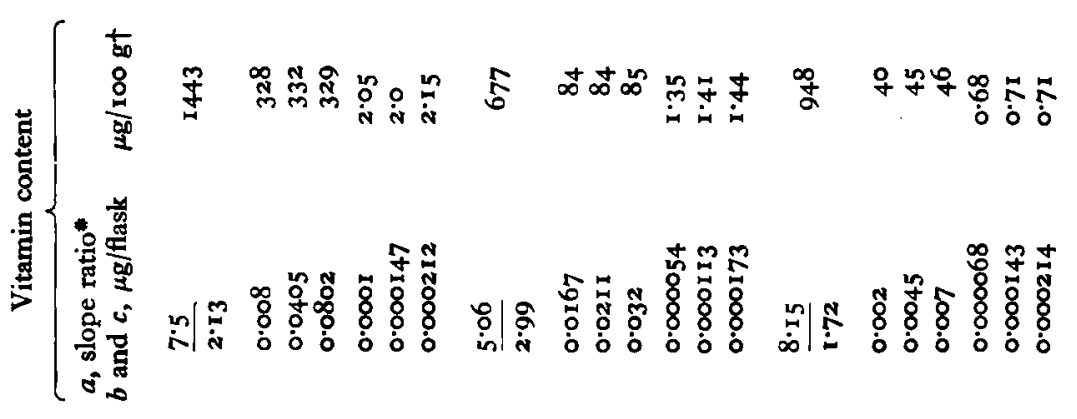

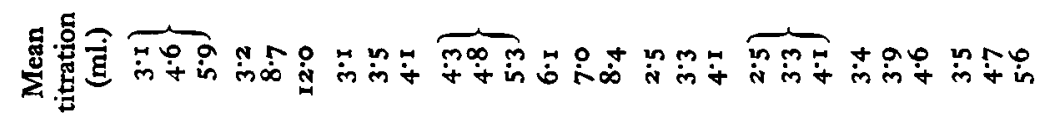

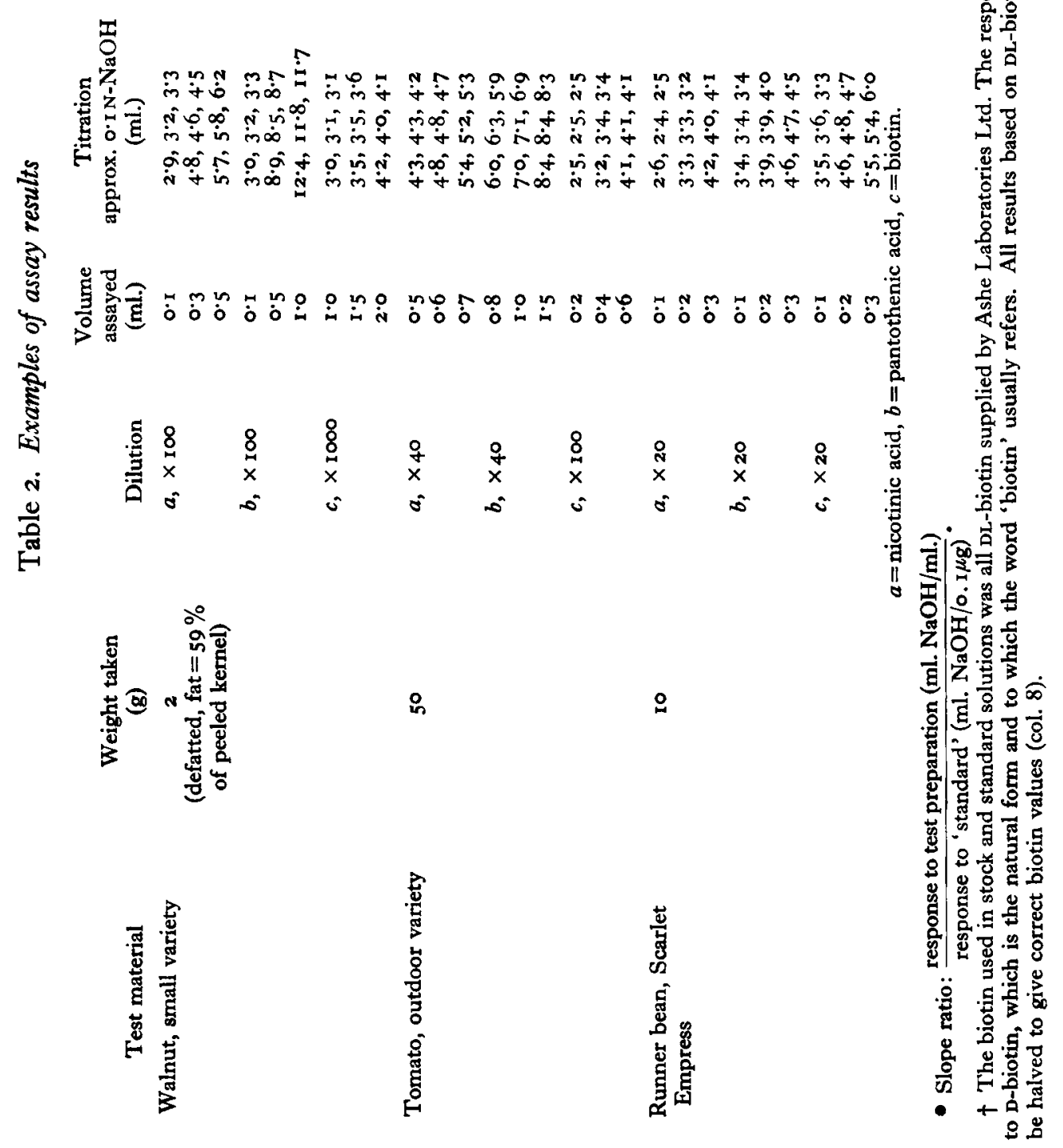


With the exception of pulse vegetables no class of fruits or vegetables appeared to be consistently richer than another in any one of these vitamins. For example, root vegetables included beetroot with a nicotinic-acid content of $110 \mu \mathrm{g} / \mathrm{I00} \mathrm{g}$, and swedes and parsnips with more than $1000 \mu \mathrm{g} / \mathrm{ro0} \mathrm{g}$. Hard fruits did, however, tend to

Table 3. Nicotinic-acid, pantothenic-acid and biotin contents of fresh fruits

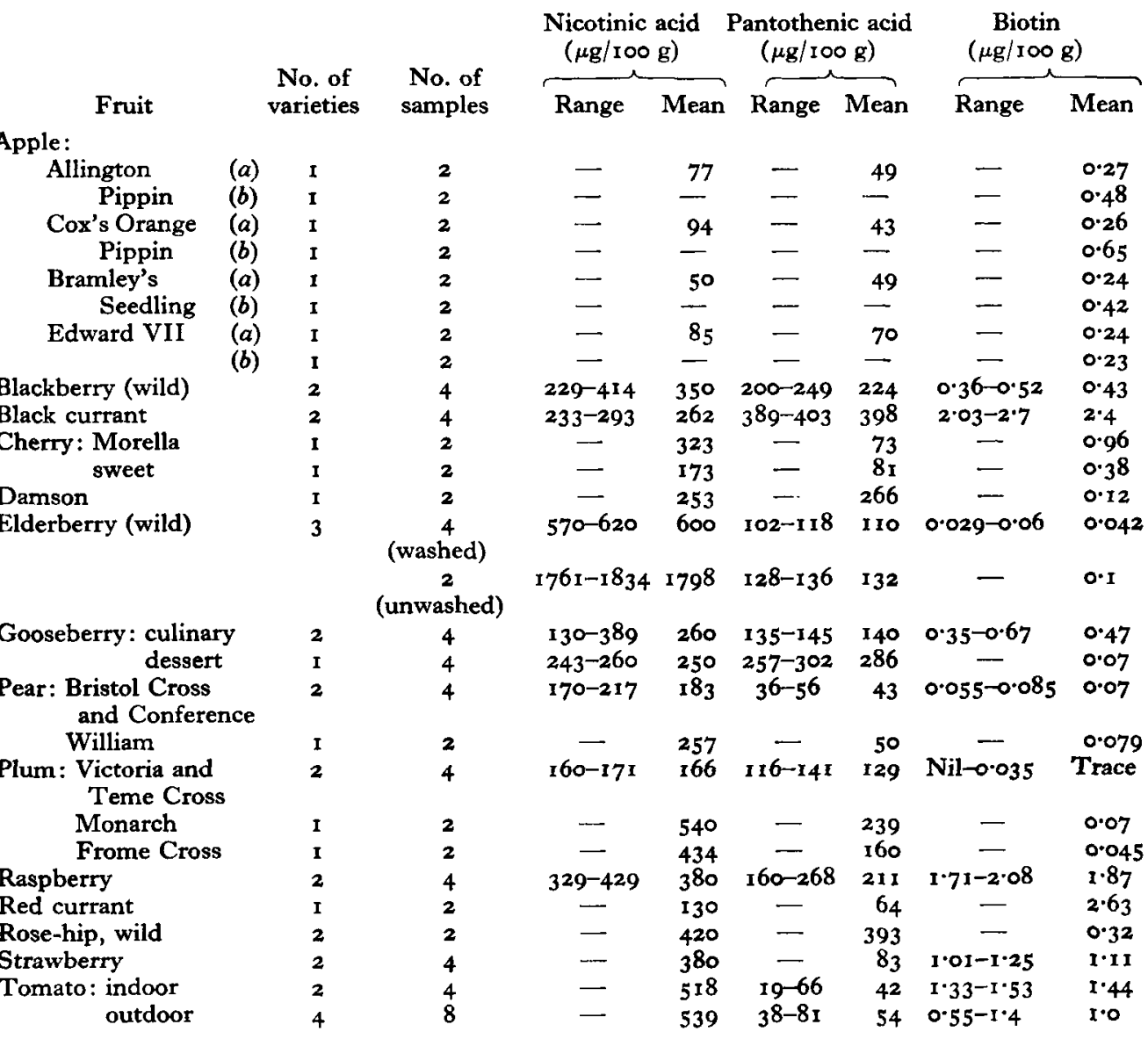

(a) I week after picking. (b) I2 weeks after picking.

be low in pantothenic-acid content. Some kinds of nuts contained far greater proportions of biotin than fruits or vegetables. Filberts and hazel nuts were outstanding in this respect, whereas almonds were surprisingly low in both biotin and pantothenic acid, but highest of all nuts examined in nicotinic acid. Chestnuts were consistently low in all three vitamins.

When assessing the nutritional value of any food, consideration must be given to the fact that the state in which a food is analysed is not always that in which it is consumed. Although in the foods concerned here extraction was always made of the fresh raw material, heating formed an essential part of the extraction process. Thus all values found are virtually of the cooked food, and the possibility of the presence of such 
systems as the avidin-biotin complex in the raw material must not be overlooked. As these assays were made on enzyme-digested extracts, the values obtained for nicotinic acid may reflect the presence of a nicotinic-acid precursor. The precursor in wheat and other biological materials has been shown (Krehl, Elvehjem \& Strong, 1944) to be

Table 4. Nicotinic-acid, pantothenic-acid and biotin contents of fresh vegetables

\begin{tabular}{|c|c|c|c|c|}
\hline Vegetable & $\begin{array}{l}\text { No. of } \\
\text { samples }\end{array}$ & $\begin{array}{l}\text { Nicotinic acid } \\
(\mu \mathrm{g} / 100 \mathrm{~g})\end{array}$ & $\begin{array}{l}\text { Pantothenic acid } \\
(\mu \mathrm{g} / 100 \mathrm{~g})\end{array}$ & $\begin{array}{c}\text { Biotin } \\
(\mu \mathrm{g} / \mathrm{r} 00 \mathrm{~g})\end{array}$ \\
\hline $\begin{array}{l}\text { Asparagus: 'choice' } \\
\text { 'selected' }\end{array}$ & $\begin{array}{l}\mathbf{I} \\
\mathbf{I}\end{array}$ & $\begin{array}{r}1000 \\
857\end{array}$ & $\begin{array}{l}174 \\
187\end{array}$ & $\begin{array}{l}0.58 \\
0.55\end{array}$ \\
\hline $\begin{aligned} \text { Bean: } & \text { broad } \\
& \text { dwarf } \\
& \text { runner }\end{aligned}$ & $\begin{array}{l}2 \\
2 \\
2\end{array}$ & $\begin{array}{c}4250 \\
376,490 \\
939\end{array}$ & $\begin{array}{c}5100,5625 \\
100 \\
45,5^{1}\end{array}$ & $\begin{array}{c}3 \cdot 22 \\
I \cdot 17,1 \cdot 36 \\
0 \cdot 7\end{array}$ \\
\hline Beetroot & 2 & 100,120 & 133,158 & $0.02,0.045$ \\
\hline Brussels sprouts & 2 & 560,760 & 320,395 & 0.43 \\
\hline Cabbage, savoy & 2 & 234 & 183 & 0.08 \\
\hline Carrot, young & 2 & 812 & 350 & 0.59 \\
\hline Cauliflower: flower & 2 & 567 & 642 & $1 \cdot 9$ \\
\hline leaf & 2 & 1400 & $4 \pi 3,470$ & 0.44 \\
\hline stalk* & $\mathbf{z}$ & $45^{8}$ & 217 & 0.14 \\
\hline $\begin{array}{l}\text { Celery: stem } \\
\text { leaf and midrib* }\end{array}$ & $\begin{array}{l}2 \\
2\end{array}$ & $\begin{array}{l}250 \\
680\end{array}$ & $\begin{array}{l}375 \\
640\end{array}$ & $\begin{array}{l}0.13 \\
0.5\end{array}$ \\
\hline Kale, curly & 2 & 1045 & $35^{\circ}$ & $0 \cdot 46$ \\
\hline Lettuce, cabbage & 2 & 319 & 44 & $0.62,0.83$ \\
\hline Leek & 2 & 588,747 & 120 & $1 \cdot 3^{8}$ \\
\hline Marrow & $\mathbf{I}$ & 265 & 103 & 0.42 \\
\hline Onion & 2 & 175 & 89 & 0.9 \\
\hline Parsley & 2 & 821 & 25 & 0.43 \\
\hline Parsnip & 2 & 980,1300 & 400 & 0.108 \\
\hline Pea & 2 & 1913,2350 & 1450,1800 & $0.43,0.66$ \\
\hline \multicolumn{5}{|l|}{$\begin{array}{l}\text { Potato, early main crop } \\
\text { (November): }\end{array}$} \\
\hline scraped & 2 & 400 & 160 & $0 \cdot 135$ \\
\hline peeled & 2 & 426 & 300 & 0.098 \\
\hline whole & 2 & 492 & 320 & 0.12 \\
\hline Spinach, perpetual & 2 & 500 & 345 & 0.15 \\
\hline Swede & 2 & 1108 & 109 & 0.08 \\
\hline Turnip: peeled & 2 & $28 I, 342$ & I8 & $0 \cdot I I$ \\
\hline whole & 2 & 750,827 & 26 & 0.053 \\
\hline Watercress & 2 & 542,644 & 70 & 0.4 \\
\hline
\end{tabular}

* All other values refer to edible parts only.

Where results on two samples differed by more than $10 \%$, both are shown.

Table 5. Nicotinic-acid, pantothenic-acid and biotin contents of home-grown nuts

\begin{tabular}{|c|c|c|c|c|}
\hline Nut & $\begin{array}{l}\text { Nicotinic acid } \\
(\mu \mathrm{g} / \mathrm{r} 00 \mathrm{~g})\end{array}$ & $\begin{array}{l}\text { Pantothenic acid } \\
(\mu \mathrm{g} / \mathrm{r} 00 \mathrm{~g})\end{array}$ & $\begin{array}{c}\text { Biotin } \\
(\mu \mathrm{g} / \mathrm{x} 00 \mathrm{~g})\end{array}$ & $\begin{array}{l}\text { Fat } \\
(\%)\end{array}$ \\
\hline $\begin{array}{l}\text { Almond* } \\
\text { Chestnut* }\end{array}$ & $\begin{array}{r}1670 \\
206\end{array}$ & $\begin{array}{r}75 \\
227\end{array}$ & $\begin{array}{l}0 \cdot 4 \\
I \cdot 3\end{array}$ & $\begin{array}{l}45 \\
17.5\end{array}$ \\
\hline Filbert" & 500 & 465 & 14.3 & 55 \\
\hline Hazel: peeled kernel & 600 & 380 & 15.8 & 58 \\
\hline whole kernel & 715 & 480 & $17 \cdot 3$ & 62 \\
\hline $\begin{array}{l}\text { Walnut: small* } \\
\text { large (Northdown clawnut)* }\end{array}$ & $\begin{array}{r}1440 \\
780\end{array}$ & $\begin{array}{l}340 \\
600\end{array}$ & $\begin{array}{l}2 \cdot 0 \\
1 \cdot 8\end{array}$ & $\begin{array}{l}59 \\
48\end{array}$ \\
\hline Sunflower seed* & 5040 & 620 & $8 \cdot 7$ & 55 \\
\hline
\end{tabular}

With the exception of walnuts, assays were made on a bulk sample of each kind from two or more sources. 
biologically active for days, and as suggested by Sohonie \& Misra (1950) it may be reasonable to suppose that values for nicotinic acid obtained by enzymic extraction represent what is biologically available to man. Check by biological assay is thus indicated.

\section{DISCUSSION}

It is interesting to note that the vegetables containing most nitrogen, namely the pulses, were found to contain most nicotinic acid. Also almonds and walnuts, which have comparatively high protein contents, contained considerably more nicotinic acid than the starchy chestnut.

The vegetables known to contain most nitrogen were also found to contain most pantothenic acid. Lipmann, Kaplan, Novelli, Tuttle \& Guirard (1947) have shown coenzyme $A$ to be a derivative of pantothenic acid, and Kaplan \& Lipmann (1948) have estimated that tomatoes contain nearly twice as much coenzyme $A$ as spinach. Here the perpetual spinach assayed contained considerably more pantothenic acid than tomatoes, indicating no correlation between coenzyme $\mathrm{A}$ and pantothenic-acid contents.

Evidence has been provided (Axelrod, Purvis \& Hofmann, 1948) that biotin forms part of an enzymically active complex, and investigation of biotin activation of deaminases (Lichstein \& Umbreit, 1947 b; Lichstein \& Christman, 1948) suggests the possibility of a biotin-adenylic acid combination in a structure similar to the di- and tri-phosphopyridine nucleotides of nicotinic acid. Its relationships to the synthesis of oleic acid (Williams \& Fieger, 1946; Williams, Broquist \& Snell, I947) and to oxalacetic acid decarboxylation (Lichstein \& Umbreit, I947a; Lardy, Potter \& Elvehjem, I947; Shive \& Rogers, I 947; Ochoa, Mehler, Blanchard, Jukes, Hoffmann \& Regan, 1947) have been indicated and suggest that biotin may be the coenzyme of oxalacetate decarboxylase. More recent work of Lardy, Potter \& Burris (I949) points to an essential role in the metabolic fixation of carbon dioxide.

Even against so incomplete a background the biotin values obtained in fruits are suggestive. With the exception of wild blackberries and elderberries, the soft fruits contained a greater amount of biotin than the hard and stone fruits. Such fruits as these, strawberries, raspberries, red currants, have a short 'mature life', which may be correlated with a high rate of cell respiration. The two exceptions may be discounted as having a much lower proportion of flesh and juice to seed than the other soft fruits examined.

Again, the four varieties of apple tested showed very similar biotin values $\left(0.24^{-}\right.$ $0.27 \mu \mathrm{g} / \mathrm{r} 00 \mathrm{~g}$ ) when assayed within a week of picking in a thoroughly unripe condition. Apples from the same batches assayed 12 weeks later differed both in maturity and in biotin content. Samples of Cox's Orange Pippin were perfectly ripe (biotin $0.65 \mu \mathrm{g} /$ I00 g) and those of Allington Pippin $(0.48 \mu \mathrm{g})$ and Bramley's Seedling $(0.42 \mu \mathrm{g})$ were semi-ripe. Samples of Edward VII were still hard and green, there being no apparent change in maturity and no increase in the biotin content.

The apparent relationship between biotin content and maturity would appear to merit further investigation. It may also serve to explain the wide variations found in the biotin contents of nuts. 


\section{SUMMARY}

I. Nicotinic acid, pantothenic acid and biotin have been estimated microbiologically in a wide range of fruits, vegetables and nuts commonly grown in the British Isles.

2. Microbiological methods of assay were used with Lactobacillus arabinosus as test organism. They proved suited to the simultaneous estimation of nicotinic acid, pantothenic acid and biotin in a single enzyme-extracted preparation of test material. The procedure followed is fully described and examples of assay results and response curves are given.

3. In fruits, amounts of nicotinic acid varied from 50 to $90 \mu \mathrm{g} / \mathrm{100} \mathrm{g}$ in apples to $260 \mu \mathrm{g} / 100 \mathrm{~g}$ in gooseberries and black currants, and $520 \mu \mathrm{g} / \mathrm{ro0} \mathrm{g}$ in tomatoes. Pantothenic-acid values ranged from 40 to $70 \mu \mathrm{g} / \mathrm{roo} \mathrm{g}$ in apples, pears and tomatoes to nearly $400 \mu \mathrm{g} / \mathrm{ro0} \mathrm{g}$ in rose-hips and black currants. Biotin was found in small quantities, from a trace in plums to $\mathrm{I} .0 \mu \mathrm{g} / \mathrm{100 \textrm {g }}$ in tomatoes and about $2.5 \mu \mathrm{g} / \mathrm{ro0} \mathrm{g}$ in red and black currants.

4. In vegetables, nicotinic-acid levels were mostly higher than in fruits. Pulse vegetables were markedly the highest in all three vitamins, broad beans containing nicotinic acid $4250 \mu \mathrm{g} / \mathrm{ro0} \mathrm{g}$, pantothenic acid $5000 \mu \mathrm{g} / \mathrm{ro0} \mathrm{g}$ and biotin $3 \mu \mathrm{g} / \mathrm{ro0} \mathrm{g}$. Other vegetables varied in nicotinic-acid content from $175 \mu \mathrm{g} / \mathrm{I00} \mathrm{g}$ in onion to $400-$ $500 \mu \mathrm{g} / 100 \mathrm{~g}$ in potato, and $1000 \mu \mathrm{g} / 100 \mathrm{~g}$ in curly kale, parsnip and asparagus. Pantothenic-acid values were found from $18 \mu \mathrm{g} / 100 \mathrm{~g}$ in turnip to $350 \mu \mathrm{g} / \mathrm{ro0} \mathrm{g}$ in curly kale and carrot and $640 \mu \mathrm{g} / \mathrm{100} \mathrm{g}$ in cauliflower. Biotin contents ranged from $<0.1 \mu \mathrm{g} / \mathrm{l} 00 \mathrm{~g}$ in beetroot, turnip and swede to nearly $0.5 \mu \mathrm{g} / \mathrm{roog}$ in brussels sprouts, parsley, watercress and curly kale, and $\mathrm{I} \cdot 9 \mu \mathrm{g} / \mathrm{r} 00 \mathrm{~g}$ in cauliflower.

5. In nuts, amounts of nicotinic acid varied from $200 \mu \mathrm{g} / \mathrm{ro0} \mathrm{g}$ in chestnuts to $600 \mu \mathrm{g} / \mathrm{ro0} \mathrm{g}$ in hazel and $\mathrm{I} 600 \mu \mathrm{g} / \mathrm{r} 00 \mathrm{~g}$ in almond; $5000 \mu \mathrm{g} / \mathrm{ro0} \mathrm{g}$ were found in sunflower seeds. Pantothenic-acid values ranged from $75 \mu \mathrm{g} / \mathrm{roog}$ in almond to $380 \mu \mathrm{g} /$ $100 \mathrm{~g}$ in hazel and $600 \mu \mathrm{g} / \mathrm{ro0} \mathrm{g}$ in walnut; $620 \mu \mathrm{g} / 100 \mathrm{~g}$ were found in sunflower seeds. Biotin was present in greater quantities than in fruits and vegetables, varying from $0.4 \mu \mathrm{g} / \mathrm{I} 00 \mathrm{~g}$ in almond to $2 \mu \mathrm{g} / \mathrm{IOO} \mathrm{g}$ in walnut and $\mathrm{r}_{4}-16 \mu \mathrm{g} / \mathrm{IOO} \mathrm{g}$ in filbert and hazel; $8.7 \mu \mathrm{g} / \mathrm{roo} \mathrm{g}$ were found in sunflower seeds.

The author is indebted to Miss E. M. Glenn of East Malling Research Station for supplying the walnut varieties and to $\mathrm{Mr}$ Cyril Vint for the samples of asparagus. Thanks are also due to Miss Crang and her assistants for help with the experimental work.

\section{REFERENCES}

Axelrod, A. F., Purvis, S. E. \& Hofmann, K. (1948). F. biol. Chem. 176, 695.

Barton-Wright, E. C. (1944). Biochem. F. 38, 314 .

Barton-Wright, E. C. (1945). Analyst, 70, 283 .

Barton-Wright, E. C. (not dated). Practical Methods for the Microbiological Assay of the Vitamin B Complex and Essential Amino Acids. London: Ashe Laboratories Ltd.

James, D. P. (1944). Long Ashton Ann. Rep., p. 166.

James, D. P. (1947). Long Ashton Ann. Rep., p. 192.

Kaplan, N. O. \& Lipmann, F. (1948). F. biol. Chem. 174, 37. 
Kodicek, E. \& Pepper, C. R. (1948). F. gen. Microbiol. 2, 292.

Krehl, W. A., Elvehjem, C. A. \& Strong, F. M. (1944). F. biol. Chem. 156, 13.

Lardy, H. A., Potter, R. L. \& Burris, R. H. (1949). Y. biol. Chem. 179, 721.

Lardy, H. A., Potter, R. L. \& Elvehjem, C. A. (I947). F. biol. Chem. I69, 45 r.

Lichstein, H. C. \& Christman, J. F. (1948). F. biol. Chem. I75, 649.

Lichstein, H. C. \& Umbreit, W. W. (1947a). F. biol. Chem. 170, 329.

Lichstein, H. C. \& Umbreit, W. W. (1947b). F. biol. Chem. 170, 423.

Lipmann, F., Kaplan, N. O., Novelli, G. D., Tuttle, L. C. \& Guirard, B. M. (1947). F. biol. Chem. 167, 869.

Mcllwain, H. \& Stanley, D. A. (1948). F. gen. Microbiol. 2, xii.

Ochoa, S., Mehler, A., Blanchard, M. L., Jukes, T. H., Hoffmann, C. E. \& Regan, M. (1947). F. biol. Chem. 170, 413 .

Price, S. A. \& Graves, H. C. H. (1944). Nature, Lond., 153, 461.

Shive, W. \& Rogers, L. L. (1947). F. biol. Chem. 169, 453.

Sohonie, K. \& Misra, U. C. (1950). Brit. F. Nutrit. 4, 134 .

Williams, V. R. \& Fieger, E. A. (1946). F. biol. Chem. 166, 335.

Williams, W. L., Broquist, H. P. \& Snell, E. E. (1947). F. biol. Chem. r7o, 6r9.

Wood, E. C. (1945). Nature, Lond., 155, 632.

Wood, E. C. (1946). Analyst, 7r, I.

\title{
Factors Affecting the Utilization of Food by Dairy Cows
}

\section{The Digestibility and Rate of Passage of Foods during L-Thyroxine Administration}

\author{
BY C. C. BALCH, D. A. BALCH, S. BARTLETT, \\ V. W. JOHNSON AND S. J. ROWLAND \\ National Institute for Research in Dairying, University of Reading
}

(Received 29 August 195 I)

It is well known that the administration of thyroid-active substances to lactating cows usually stimulates milk secretion and, in this way, may affect the efficiency of food utilization. Until recently iodinated protein was the cheapest and most suitable thyroid-active substance available, but synthetically produced L-thyroxine, given by mouth, now appears to be the most suitable material (Bailey, Bartlett \& Folley, 1949). The administration of thyroid-active substances raises the metabolic rate and increases the nutritive requirements of cows. The literature on this subject has been reviewed by Blaxter, Reineke, Crampton \& Petersen (1949), and further results have been reported by Moustgaard \& Thorbek (1949). The experiment described in this paper was an attempt to find whether this increased requirement is met, even partly, by a more efficient digestion of available food or whether the cows can obtain additional nutrients only by eating more food or utilizing body reserves.

The administration of thyroid-active materials is known to increase the rate of stomach emptying and intestinal motility in non-ruminants (see review by Ivy, 1930). In cows the administration of iodinated protein (Blaxter, 1946) and of thyroxine (Owen, r948) is known to produce moister faeces, and the same effect has been observed in sheep given heavy doses of iodinated casein (Blaxter, 1948); this has sometimes been thought to signify a faster rate of passage of food. The effect of an in- 